\title{
6th International Conference of the International Society for Industrial Ecology 参加報告
}

烟山 博樹・平木 岳人

\section{Report on the 6th International Conference of the International Society for Industrial Ecology}

\author{
Hiroki HATAYAMA and Takehito HIRAKI
}

\section{1.はじめに}

2011年6月7日から 10 日にかけて、アメリカのカリフォ ルニア大学バークレー校において、International Society for Industrial Ecology (ISIE) が主催する第6回の国際会議 (ISIE2011) が開催された。ISIEは研究、教育、政策、地 域開発、企業活動といったなかでの産業生態学の活用を促 進することを使命としており、2001年の発足より研究者、 技術者、政策決定者らが複雑な環境問題の解決を目指し て議論する場となっている。国際会議は2001年より隔年 で開催されており、6回目となる今回の会議にはScience, Systems, and Sustainabilityという副題が添えられた。 概要については、ISIE2011ホームページ (http://isie2011. berkeley.edu/index.html) もご参考いただきたい。

\section{2. 発表人数および参加人数}

運営委員会の発表によれば、今回の会議の発表申込件数 は760件にも上った。前回までの会議における発表は 200 件、 参加は 300 名程度であり、本研究分野への関心が近年高 まっているとはいえ劇的な増加と言うべき状況であった。 この申込件数は運営委員会の想定をはるかに超えるもので あり、結果として発表件数は516件 (プログラム掲載分) で

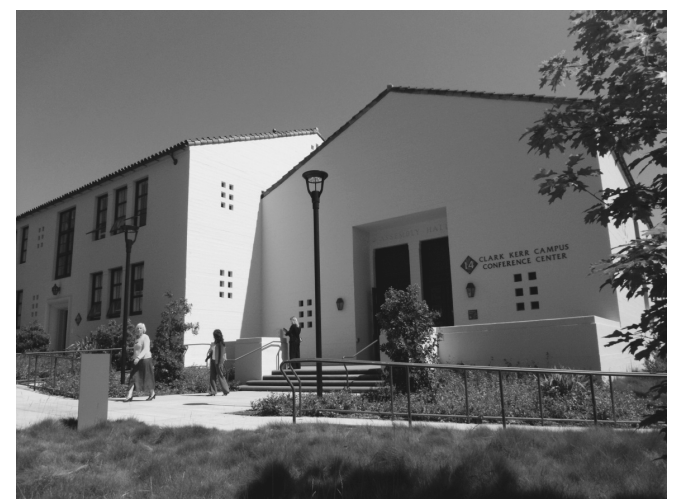

図 1 メイン会場外観(CLARK KERR CAMPUS 14 号館)
あった。また、参加者も500名強と発表されたことから、 発表者以外の参加はほぼ認められなかったと推測される。 日本からの参加者は 45 名ほどであり、森口祐一氏 (国立環 境研究所、現東京大学) はCo-chair として会議の運営に参 画した。

\section{3. 研究発表の内容}

最初に、ローレンス・バークレー国立研究所のArthur Rosenfeld氏による基調講演がおこなわれた。講演では、 アメリカにおいて多くの犠牲者を出してきた熱波について 解説されるとともに、使用エネルギーや居住する建物を含 めた人間の生活スタイルと熱波の関係、自然環境と向き合 う姿勢など非常に広い視野で検討した研究が報告された。

その後の研究発表では、375件の口頭発表と141件のポ

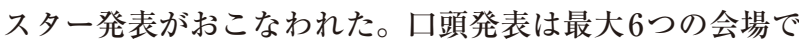
の同時進行となった。また、ポスターは3日間にわかれて の発表となった。今回の会議におけるセッションと口頭発 表件数を表 1 に示す。エネルギー、資源、都市計画、各種 フットプリントなど幅広い分野にわたって環境影響の可視 化やその手法論の検討がなされた。今回の会議は、表 $1 の$ “6. Scenario Development and Analysis” や “17. Policy Intervention and Planning”で議論されたような、シナリ オを設定しての分析の発表が多かったのが特徴である。こ れらのセッションでは、手法や適用分野が限定されておら ず、次世代自動車や新エネルギーシステムの導入、温室効 果ガスの排出に対する規制などを考慮した様々な将来志向 型の研究発表がなされた。環境負荷の低減に向けて多くの 方策が検討される近年の状況から、分析手法を活用して の実際の評価が多く取り組まれるようになったと考えられ る。将来的には、評価結果を反映した政策実施や企業運営 について、意思決定者からの報告が増えることを期待した い。 
表1 セッション名一覧およびロ頭発表の内訳

\begin{tabular}{|c|c|}
\hline Topics & Number of Presentations \\
\hline 1. Material Flow Analysis & 15 \\
\hline 2. Life-cycle Methodology & 32 \\
\hline 3. Environmentally Extended Input-Output Analysis & 21 \\
\hline 4. Life-cycle Management \& Organization of Product Chains & 10 \\
\hline 5. Complex Systems and Agent Modeling & 10 \\
\hline 6. Scenario Development and Analysis & 52 \\
\hline 7. Eco-Industrial Development and Industrial Systems & 25 \\
\hline 8. Eco-Design: Products and services for the Future & 5 \\
\hline 9. Managing End-of-Life Products & 15 \\
\hline 10. Footprint Analysis, Reporting and Communication & 22 \\
\hline 11. Eco-efficiency & 4 \\
\hline 12. Energy Systems & 29 \\
\hline 13. Sustainable Cities and Urban Metabolism & 21 \\
\hline 14. Sustainable Water Systems & 12 \\
\hline 15. Industrial Ecology in Developing Countries & 14 \\
\hline 16. Sustainable Consumption and Behavior & 14 \\
\hline 17. Policy Intervention and Planning & 29 \\
\hline 18. Food and Agricultural Systems & 4 \\
\hline 19. Transportation and Logistics & 15 \\
\hline 20. Buildings and Infrastructure Systems & 10 \\
\hline 21. Alternative Fuels & 10 \\
\hline 22. Biomass and Bioenergy & 6 \\
\hline $\begin{array}{r}\text { Total } \\
\end{array}$ & 375 \\
\hline
\end{tabular}

筆者が主に聴講した “1. Material Flow Analysis”、“6. Scenario Development and Analysis”、“13. Sustainable Cities and Urban Metabolism”といったセッションでは、 資源利用に関する研究発表が多くおこなわれた。特に、 資源消費だけでなくそれに付随する環境負荷をあわせて 示す研究が以前に比べ増加したように感じられた。多く 示されたのはエネルギー消費量および $\mathrm{CO}_{2}$ である。例え ば “From Liquid Metal to Products: Mapping the Global Flow of Steel and Aluminum” (J. M. Cullen et al.)では、 鉄鋼とアルミニウムの生産から使用までに必要とされるエ ネルギー量が示された。さらに直接的なエネルギー消費だ けでなく「エネルギー損失」が計算されており、これは資源 消費でいうところの関与物質総量 (TMR) の概念を用いて 推計されたとみられる。“The $\mathrm{CO}_{2}$ Impact of Yield: Case Studies along Steel and Aluminum Supply Chains” (R. Milford et al.) では、サプライチェーンの各段階における 材料歩留の向上による $\mathrm{CO}_{2}$ 排出量の削減効果が示された。 また、“Measuring and Controlling National Consumption of Global Resources” (S. Bringezu) では、関与物質総量 が大きいことによる土地へのダメージについて言及がなさ れた。
他の環境負荷を考慮しないマテリアルフロー分析も発表 されたが、多くは鉄鋼やアルミニウムといった素材が対象 となっており、中国などの途上国を意識したものが多かっ た。近年は希少金属にも注目が集まっているが、前述のよ うにエネルギー消費などを議論するうえでは結局消費規模 の大きなものが重要視されるということであろう。ただ、 新规材料を対象とするような、新しい取り組みも始まっ ているようである(“Substance Flow Analysis of Novel Compounds: The Case of Graphene" (R. Arvidsson et $a l)$.$) 。$

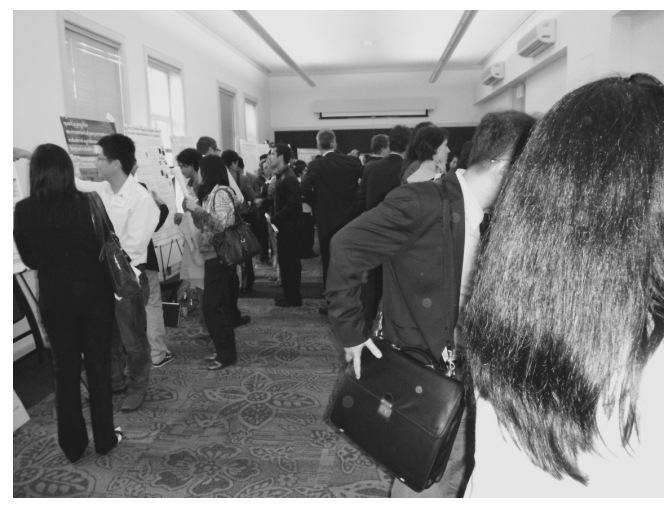

図2 ポスター発表会場 
社会的な要素を考慮した研究もいくつか発表がなさ れた。経済の一般均衡モデルを用いての資源循環の分 析 (“The Limit of Resource Circulation to Address Resources Supply Constraints: A Scenario Analysis Using a Combination of Material Flow Analysis and Multi-sectoral Growth Model” (T. Yano et al.)) は、今 後も改良を重ねつつ政策の有効性の検討に貢献すること が期待される。人々の日々の生活行動と素材需要を関連 付ける研究 (“Exploring High-resolution Urban Resource Demands with Activity-based Modelling” (J. Keirstead et al.) や、素材産業に関わる労働者の世界分布を明らか にして児童労働の問題にアプローチする研究 (“Assessing the Potential of Social MFA” (L. Schneider et al.)) など も興味深いものであった。

\section{4. おわりに}

会場となったキャンパスは小高い山の中腹に位置して多 くの木々と明るい陽射しに包まれており、西海岸のイメー ジ通りといった様子であった（ただし気温は最高 $\left.16^{\circ} \mathrm{C}\right) 。$ 夏季休暇のため周辺に学生の姿はまばらで、ゆったりとし た街の一角で濃密な議論がおこなわれることとなった。 研究発表以外にも、初日と 2 日目のディナーや分野ごとの ミーティングなど、交流を深めると同時に今後の展開を議 論する機会が多く設けられた。

クロージングではISIEの学会賞の表彰がおこなわれ、 Society Prizeがライデン大学のGjalt Huppes氏に、若 手を対象とするLaudise Prizeがノルウェー工科大学の Anders Stromman氏に授与された。また、次回 (2013年) の開催地が韓国の蔚山と発表された。2001年のライデン (オランダ) での第 1 回国際会議以降ヨーロッパと北米で交 互に開催されてきたが、ついにアジアが舞台となる。今回 の会議では途上国、特に中国に焦点をあてた発表が多くな された。成長するアジアに向けた世界の期待に応えるべ く、日本からも積極的な参加をおこないたい。 